AGRICULTURE AND BIOLOGY JOURNAL OF NORTH AMERICA

ISSN Print: 2151-7517, ISSN Online: 2151-7525, doi:10.5251/abjna.2011.2.10.1351.1354

C 2011, ScienceHu $\beta$, http://www.scihub.org/ABJNA

\title{
Response of plant and ratoon crop plantain to potassium fertilization in the tropical rain forest zone of Nigeria
}

\author{
John Okokoh Shiyam and Olarenwaju Samuel Bello
}

\author{
Faculty of Agriculture, University of Calabar, P.M.B.1115, Calabar 540001, Cross \\ River State, Nigeria
}

\begin{abstract}
Nutrient potassium is critical in plantain (Musa spp. cv. AAB) nutrition and may play a key role in its vegetative growth and bunch development. Growth of both plant and ratoon crops was enhanced by application of $400 \mathrm{~kg} \mathrm{k} 0 / \mathrm{ha}$. Tallest plants were $350 \mathrm{~cm}$ tall with thickest trunks or pseudostem (56 $-58 \mathrm{~cm}$ thick) girth, had highest (11-12) number of functional leaves/plant at flowering and attained the booting stage after nine months of vegetative growth. Application of $300 \mathrm{~kg}$ muriate of potash $\left(\mathrm{K}_{2} \mathrm{O}\right)$ per hectare to the plant crop and $400 \mathrm{~kg} \mathrm{~K} \mathrm{~K}_{2} \mathrm{O} / \mathrm{ha}$ to the ratoons significantly $(P=0.05)$ influenced the bunch yield and yield components (number of hands and fingers/bunch, finger mass, girth and length). Bunch yield increased with increasing K20 rates applied. Highest bunch yield increases of 5.86 and 6.00 tonnes/ha were obtained by fertilizing the plant and ratoon crops with 300 and $400 \mathrm{~kg}$ k20/ha, respectively. Heaviest bunches were 8.8 and $9.8 \mathrm{~kg} / \mathrm{plant}$ in plant and ratoon crops, giving the respective corresponding bunch yields of 15.7 and 16.3 tonnes/ha. An application of $300 \mathrm{~kg} \mathrm{~K}_{2} \mathrm{O} / \mathrm{ha}$ to the plant crop and $400 \mathrm{~kg} \mathrm{~K} 20 / \mathrm{ha}$ at the ratoon stage would be adequate for sustainable productivity of False Horn plantain in the high rainforest zone of Cross River State, Nigeria.
\end{abstract}

Key words: Growth cycle, plantain, potassium, rainforest.

\section{INTRODUCTION}

Smallholder commercial cultivation of plantain in Nigeria is expanding at a very fast rate to meet the continuously increasing demand for the crop especially in the expanding urban centres (Obiefuna, 1986). However, several soils supporting plantain in West Africa including those in Nigeria are of low productivity (Woomer and Muchena, 1993; Ofori, 1996) and comprise about $70 \%$ of the tropical soils on which plantain is grown (Sanchez, 1976)

The predominantly low yield of plantain and the characteristic rapid yield decline under field conditions was usually attributed to soil fertility constraints (Irizzarry et al., 1989; Swennen, 1990 and IITA, 1995). Appropriate agronomic practices such as fertilizer application and mulching plantain with organic materials have enhanced the productivity of the crop (Swennen, 1990). However, potassium, which is one of the major elements required by plantain is often the most important limiting nutrient element in many tropical soils (Yayock et al., 1988) especially in the plantain zone particularly due to luxury or excessive uptake of the nutrient by the crop (Robinson, 1996).

Potassium may be added to the soil through the return of crop residues and ash or through inorganic fertilizers and organic manures. Under intensive and continuous cultivation, inorganic fertilizers appear to be the most dependable source of plant nutrients for the production of plantain. Information is currently lacking on potassium requirement of the crop especially in the high rainforest area of Cross River State which is one of the major plantain producing areas in Africa. Our objective was to evaluate the response of false horn plantain to potassium as well as the optimum rate of application in the rain forest belt of Cross River state, Nigeria.

\section{MATERIAL AND METHODS}

The study was conducted at the Crop Research Farm of the University of Calabar $\left(05^{\circ} 32^{\prime}\right.$ and $04^{\circ} 27^{\prime} \mathrm{N}$; $07^{\circ} 15^{\prime}$ and $09^{\circ} 28^{\prime} \mathrm{E}$; 37 meters above sea level), Nigeria. The area is within the rainforest zone of southeastern Nigeria and has a mean relative humidity of $85 \%$, an annual rainfall of $2000-2500$ $\mathrm{mm}$, and maximum and minimum temperatures of 33 ${ }^{0} \mathrm{C}$ and $23{ }^{\circ} \mathrm{C}$, respectively. The land was cleared manually using a machete and tilled with a spade. Plot size measured $3.0 \mathrm{~m} \times 10.0 \mathrm{~m}\left(30.0 \mathrm{~m}^{2}\right)$ separated by $1.0 \mathrm{~m}$ alley - ways. Fertilizer treatments evaluated were control, $100,200,300$ and $400 \mathrm{~kg}$ of potash $\left(\mathrm{K}_{2} \mathrm{O}\right)$ per hectare. Treatments were arranged into a randomized complete block design with three replications. 
Agric. Biol. J. N. Am., 2011, 2(10): 1351-1354

Plots were established on 20 June 2005 and terminated after harvest of the first ratoon crop. Suckers were planted in $0.3 \mathrm{~m} \times 0.3 \mathrm{~m} \times 0.3 \mathrm{~m}$ holes at $2.0 \mathrm{~m} \times 3.0 \mathrm{~m}$ (1666 plants per hectare). All plots were mulched with sawdust at 20 tonnes/ha one week after planting. Mulch was applied in such a way that entire plots and paths were completely and permanently covered with $3 \pm 0.5 \mathrm{~cm}$ thick sawdust mulch layer throughout the duration of the experiment. The $\mathrm{K}_{2} \mathrm{O}$ rates applied to plant and ratoon plantains were split applied in six equal installments at $3,6,9,12.15$ and 18 months after planting (MAP) for maximum uptake by the crop. Fertilizer was applied $2-3 \mathrm{~cm}$ deep in a ring $50 \mathrm{~cm}$ from the base of the plant and covered completely with soil.

Suckers were managed in such a way that only one daughter sucker was maintained to succeed the mother plant after harvest. Weeds were removed regularly by hand pulling and hand hoeing. Soil was added at the base of plants to control high mat. Dead and diseased leaves were pruned regularly while bamboos and wooden poles were used to prop hearing plants to prevent lodging or breaking of pseudostems due to wind and heavy bunches. Data were collected on vegetative growth parameters (plant height, girth, functional leaves, time of flowering) and bunch yield indices (bunch mass, number of hands and fingers per bunch, finger mass, girth and length) for plant and ratoon crops. The data were analyzed statistically using analysis of variance (ANOVA) and treatment means were compared using. Duncan's multiple range test (DMRT) at $5 \%$ level of probability.

\section{RESULT AND DISCUSSION}

The pseudostem height and girth, number of functional leaves on the plant at flowering and time from planting to flowering varied significantly $(P=$ 0.05) among the treatments and were most favourable in plant and ratoon plants fertilized with $400 \mathrm{~kg} \mathrm{~K}_{2} \mathrm{O} / \mathrm{ha}$ (Table 1). Heights of Plant and ratoon crops exceeded those of control plants by $23 \mathrm{~cm}$ and $17 \mathrm{~cm}$ respectively, and had five more functional leaves at flower initiation, indicating rapid vegetative growth at this fertility level. Plants in this treatment also flowered 3 - 7 months earlier than those in control plots which grew slowly over a long vegetative phase.

The superior vegetative growth of plantains in plots treated with $400 \mathrm{~kg} \mathrm{k}_{2} \mathrm{O} / \mathrm{ha}$ may be an indication of adequate potassium nutrition in addition to possible improvements in physical and biotic soil conditions and microclimate. The luxuriant growth of plantain in terms of rapid leaf production and plant vigour due to a mulching effect and optimum nutrient uptake was similarly reported in previous studies (Obiefuna, 1986; Salau et al, 1992; Swennen, 1990). In contrast, the poor growth of the crop as shown by late flowering in control plots was due mainly to low soil fertility status.

The bunch mass and all yield components of plant and ratoon crops except the number of hands per bunch, responded significantly $(p=0.05)$ to potassium fertilization (Table 2). Plant crop fertilized with potassium at $300 \mathrm{~kg} \mathrm{~K} \mathrm{~K}_{2} \mathrm{O} / \mathrm{ha}$ produced the heaviest $(P=0.05)$ bunches with superior bunch characteristics and highest bunch yields per hectare. Plant crop fertilized with $300 \mathrm{~kg} \mathrm{~K}$ O/ha also exhibited rapid vegetative growth and early flower initiation, resulting in early bunch harvest four months before the non-fertilized plantains.

Sucker growth represented by the height of the succeeding sucker at harvest of the plant crop was very rapid in plots fertilized with $300 \mathrm{~kg} \mathrm{~K} \mathrm{O} / \mathrm{ha}$. This level of $\mathrm{K}_{2} \mathrm{O}$ fertilization also stimulated fast growth of the succeeding ratoon, early flowering and early bunch maturity/harvest and shortest production cycle of only nine months between the plant and ratoon crop harvests. The best growth and favourable yield components recorded at $300 \mathrm{~kg} \mathrm{k}_{2} \mathrm{O} / \mathrm{ha}$ in the plant crop could be due to favourable soil nutrient conditions at the initial stage of establishment as the land fallowed for over five years before commencement of this trial.

In contrast, the production cycle was longer by 12 months in zero $\mathrm{k}_{2} \mathrm{O}$ plots, indicating slow plantain growth possibly due to nutrient, especially potassium deficiency as reported in Salau et al. (1992) and Robinson (1996).

The highest $\mathrm{K}_{2} \mathrm{O}$ rate $(400 \mathrm{~kg} \mathrm{~K} \mathrm{~K} / \mathrm{ha})$ was most effective at the ratoon crop stage, producing significantly $(P=0.05)$ the heaviest bunches and hence, highest bunch yield (Table 3). The bunches produced at the highest $\mathrm{K}_{2} 0$ rate were $3.6 \mathrm{~kg}$ heavier than those produced in control plants, resulting in 6.0 tonnes/ha $(60 \%)$ higher yield, harvested six months earlier than ratoon plants in control plots Ratoon crop plantain required higher $\mathrm{K}_{2} \mathrm{O}$ fertilizer for optimum vegetable growth and bunch yield than the plant crop. This higher requirement might be due to soil nutrient depletion arising from plant crop uptake as well as leaching losses. Thus the ratoon crop would respond to high $\mathrm{k}_{2} \mathrm{O}$ 
Table 1: Effect of potassium fertilization on vegetative growth of plant and first ratoon plantains (cv. 'Agbagba') at flowering.

\begin{tabular}{|c|c|c|c|c|c|c|c|c|}
\hline \multirow[b]{2}{*}{ Treatment } & \multicolumn{4}{|c|}{ Plant crop } & \multicolumn{4}{|c|}{ First ratoon plants } \\
\hline & $\begin{array}{l}\text { Pseudostem } \\
\text { height }(\mathrm{cm})\end{array}$ & $\begin{array}{l}\text { Girth ( } \mathrm{cm} \\
{ }^{*} \text { ) }\end{array}$ & $\begin{array}{l}\text { Number of } \\
\text { functional } \\
\text { leaves on } \\
\text { the plant }\end{array}$ & $\begin{array}{l}\text { Time to } 50 \% \\
\text { flowering } \\
\left(\mathrm{MAP}^{\star *}\right)\end{array}$ & $\begin{array}{l}\text { Pseudostem } \\
\text { height }(\mathrm{cm})\end{array}$ & $\begin{array}{l}\text { Girth } \quad t \\
(\mathrm{~cm})\end{array}$ & $\begin{array}{l}\text { Number of } \\
\text { functional } \\
\text { leaves on } \\
\text { the plant }\end{array}$ & $\begin{array}{l}\text { Time to } 50 \% \\
\text { flowering } \\
\text { (MAP) }\end{array}$ \\
\hline Control & $300 c$ & $41 d$ & $6.2 \mathrm{c}$ & $13.0 \mathrm{~b}$ & $333 b$ & $38 \mathrm{c}$ & $6.8 \mathrm{c}$ & $25.5 a$ \\
\hline $100 \mathrm{~kg} / \mathrm{k}_{2} \mathrm{O} / \mathrm{ha}$ & $342 b$ & $47 c$ & $8.8 b$ & $10.8 c$ & $344 b$ & $50 b$ & $9.6 \mathrm{~b}$ & $18.2 a$ \\
\hline $200 \mathrm{~kg} / \mathrm{k}_{2} 0 / \mathrm{ha}$ & $343 b$ & $51 \mathrm{~b}$ & $8.7 \mathrm{~b}$ & $10.4 \mathrm{c}$ & $342 c$ & $51 b$ & $7.4 \mathrm{c}$ & $19.8 c$ \\
\hline $300 \mathrm{~kg} / \mathrm{k}_{2} \mathrm{O} / \mathrm{ha}$ & $353 a$ & $54 a$ & $10.8 \mathrm{a}$ & $9.5 d$ & $34 a$ & $57 a$ & $10.0 \mathrm{~b}$ & $16.3 d$ \\
\hline $400 \mathrm{~kg} / \mathrm{k}_{2} \mathrm{O} / \mathrm{ha}$ & $353 a$ & $56 a$ & $11.0 \mathrm{a}$ & $9.3 d$ & $350 a$ & $58 a$ & $11.8 \mathrm{a}$ & $18.5 c$ \\
\hline
\end{tabular}

${ }^{*}$ measured $1 \mathrm{~m}$ from soil surface, ${ }^{\star \star}$ Months after planting.

Means in the same column followed by the same letter are not significantly different at $5 \%$ level of probability according to Duncan's multiple range test (DMRT).

\begin{tabular}{|c|c|c|c|c|c|c|c|c|c|}
\hline Treatment & $\begin{array}{c}\text { Bunch } \\
\text { mass } \\
\text { (kg/plant) }\end{array}$ & $\begin{array}{l}\text { Number } \\
\text { of hands/ } \\
\text { bunch }\end{array}$ & $\begin{array}{l}\text { Number of } \\
\text { fingers/bunch }\end{array}$ & $\begin{array}{l}\text { Individual } \\
\text { finger } \\
\text { mass }(\mathrm{g})\end{array}$ & $\begin{array}{c}\text { Finger } \\
\text { girth }(\mathrm{cm})\end{array}$ & $\begin{array}{l}\text { Finger } \\
\text { length } \\
(\mathrm{cm})\end{array}$ & $\begin{array}{c}\text { Height of } \\
\text { primary } \\
\text { sucker at } \\
\text { harvest }(\mathrm{cm})\end{array}$ & $\begin{array}{c}\text { Time to } 50 \% \\
\text { harvest } \\
\text { (MAP) }\end{array}$ & $\begin{array}{c}\text { Bunch yield } \\
\text { (tones/ha) }\end{array}$ \\
\hline Control & $5.8 \mathrm{c}$ & $6.0 \mathrm{a}$ & $28.7 c$ & $155 c$ & $13.9 c$ & $13.8 b$ & $124 d$ & $16.0 \mathrm{a}$ & $9.70 c$ \\
\hline $100 \mathrm{~kg} / \mathrm{k}_{2} 0 / \mathrm{ha}$ & $6.9 \mathrm{~b}$ & $6.7 a$ & $31.7 b$ & $176 c$ & $14.6 \mathrm{~b}$ & $15.9 a$ & $188 \mathrm{c}$ & $15.2 b$ & $11.50 \mathrm{~b}$ \\
\hline $200 \mathrm{~kg} / \mathrm{k}_{2} 0 / \mathrm{ha}$ & $7.2 \mathrm{~b}$ & $6.7 a$ & $33.0 \mathrm{a}$ & $172 c$ & $14.3 \mathrm{~b}$ & $16.2 \mathrm{a}$ & $220 b$ & $14.0 \mathrm{~b}$ & $12.00 \mathrm{~b}$ \\
\hline $300 \mathrm{~kg} / \mathrm{k}_{2} 0 / \mathrm{ha}$ & $8.8 \mathrm{a}$ & $6.7 a$ & $34.0 a$ & $2.2 a$ & $15.8 \mathrm{a}$ & $16.9 a$ & $228 a$ & $12.5 \mathrm{~b}$ & $14.66 a$ \\
\hline $400 \mathrm{~kg} / \mathrm{k}_{2} 0 / \mathrm{ha}$ & $8.2 \mathrm{a}$ & $6.7 a$ & $32.3 b$ & $195 a$ & $15.3 a$ & $16.8 \mathrm{a}$ & $226 a$ & $13.3 d$ & $13.66 a$ \\
\hline
\end{tabular}

Means in the same column followed by the same letter are not significantly different at $5 \%$ level of probability according to Duncan's multiple range test (DMRT).

Table 3: $\quad$ Effect of potassium fertilization on bunch mass, yield components and bunch yield of first ratoon crop of a false horn plantain (cv. 'Agbagba') .

\begin{tabular}{|c|c|c|c|c|c|c|c|c|}
\hline Treatment & $\begin{array}{c}\text { Bunch } \\
\text { mass } \\
\text { (kg/plant }\end{array}$ & $\begin{array}{c}\text { Number of } \\
\text { hands/ } \\
\text { bunch }\end{array}$ & $\begin{array}{c}\text { Number of } \\
\text { fingers/bunch }\end{array}$ & $\begin{array}{c}\text { Individual } \\
\text { finger weight } \\
(\mathrm{cm})\end{array}$ & $\begin{array}{l}\text { Finger girth } \\
(\mathrm{cm})\end{array}$ & $\begin{array}{l}\text { Finger height } \\
(\mathrm{cm})\end{array}$ & $\begin{array}{l}\text { Time to } 50 \% \\
\text { harvest (MAP) }\end{array}$ & $\begin{array}{c}\text { Bunch } \\
\text { yield } \\
\text { (tones/ha) }\end{array}$ \\
\hline Control & $6.2 \mathrm{~d}$ & $6.0 \mathrm{a}$ & $32.0 d$ & $160 \mathrm{e}$ & $15.8 b$ & $14.3 \mathrm{c}$ & $27.3 b$ & $10.33 d$ \\
\hline $100 \mathrm{~kg} / \mathrm{k}_{2} \mathrm{O} / \mathrm{ha}$ & $7.3 \mathrm{c}$ & $6.7 a$ & $32.7 d$ & $201 b$ & $16.8 b$ & $16.2 b$ & $25.4 \mathrm{c}$ & $12.16 \mathrm{c}$ \\
\hline $200 \mathrm{~kg} / \mathrm{k}_{2} \mathrm{O} / \mathrm{ha}$ & $7.5 \mathrm{c}$ & $6.0 \mathrm{a}$ & $33.7 c$ & $198 c$ & $16.5 \mathrm{~b}$ & $15.5 c$ & $23.6 d$ & $12.50 \mathrm{c}$ \\
\hline $300 \mathrm{~kg} / \mathrm{k}_{2} \mathrm{O} / \mathrm{ha}$ & $9.0 \mathrm{a}$ & $6.7 a$ & $40.0 \mathrm{~b}$ & $210 a$ & $17.2 \mathrm{a}$ & $17.0 \mathrm{a}$ & $22.6 \mathrm{e}$ & $15.66 \mathrm{a}$ \\
\hline $400 \mathrm{~kg} / \mathrm{k}_{2} \mathrm{O} / \mathrm{ha}$ & $9.8 a$ & $7.7 a$ & $43.3 a$ & $220 a$ & $78.8 \mathrm{a}$ & $18.8 \mathrm{a}$ & $22.2 \mathrm{e}$ & $16.33 a$ \\
\hline
\end{tabular}

Means in the same column followed by the same letter are not significantly different at $5 \%$ level of probability according to Duncan's multiple range test (DMRT). 


\section{CONCLUSION}

Optimum $\mathrm{K}_{2} \mathrm{O}$ fertilization is beneficial to plantain as the crop has a heavy requirement for the nutrient. Fertilizer $\mathrm{K}$ enhanced vegetative growth and sustained high bunch production. Fertilizing plantain with $300 \mathrm{~kg} \mathrm{~K} \mathrm{~K}_{2} \mathrm{O} / \mathrm{ha}$ in the first cycle and $400 \mathrm{~kg}$ $\mathrm{k}_{2} \mathrm{O} / \mathrm{ha}$ at the ratoon stage would be adequate for sustainable productivity of plantain in the rainforest zone of Cross River State of Nigeria.

\section{REFERENCES}

International Institute for tropical Agriculture (IITA) 1995. IITA Research No.11, September, 1995

Irizarry, H; Rivera, E. and Rodriguez, J. 1989. Nutrient uptake and dry matter composition in the plant crop and first ratoon of the Grand Nain banana grown on an Ultisol. Journal of Agriculture of the University of Peuto Rico, 72(3) (July, 1998), 337 - 351.

Obiefuna, J. C. (1986). The effect of sawdust mulch and increasing levels of nitrogen on the weed growth and yield of Falsehorn plantain (Musa AAB). Biological Agriculture and Horticulture 3:353 - 359.

Ofori C. S. 1996. Towards the development and technology transfer of soil Management Practices for Increased Agricultural Production in Africa. In:
Ahenkoran, Y. Owusu-Bennoah, E. and Dowuuona, G. N. N. (eds) Sustaining Soil Productivity in Intensive African Agriculture. Pp. 25 - 32.

Robinson, J. C. 1996. Bananas and plantains. CAB International. U. K. 238pp.

Salau, O. A; Opara-Nadi, O. A. and Swennen, R. 1992. Effect of mulching on soil properties and yield of plantain on a tropical Ultisol in Southeastern Nigeria. Soil and Tillage Research 23 (1992): 73 - 93.

Sanchez, P. A. 1976. Properties and Management of soils in the tropics. John Wiley and Sons, New York, USA $618 \mathrm{pp}$.

Swennen, R. 1990. Plantain cultivation under West African Conditions (A Reference Manual). IITA, Ibanan, Nigeria. Pp 1-2.

Woomer, P. L. and Muchena, F. N 1993. Overcoming soil constraints in crop production in Africa. In: Ahenkoran, Y. Owusu-Bennoah, E. and Dowuuona, G. N. N. (eds) Sustaining Soil Productivity in Intensive African Agriculture. Pp. 45 - 56.

Yayock, Y. Lombin, G. and Owonubi, J. J. 1988. Crop Science and production in warm climates $1^{\text {st }}$ edition (1988) Macmillan Publishers Ltd. London Basingstoke, 407p. 